\title{
A Virtual Learning Object (VLO) to Promote Reading Strategies in an English for Specific Purposes Environment
}

\author{
Un objeto virtual de aprendizaje (OVA) para promover estrategias \\ de lectura en un ambiente de inglés con propósitos específicos
}

\section{Hernández Urrego, Sandra Cecilia ${ }^{1}$}

\begin{abstract}
This study describes the influence of a Virtual Learning Object in the promotion of reading strategies in a class of English for Specific Purposes for the majors of Social Communication and Journalism at a private institution of higher education in Bogota, Colombia. Students' failure to meet the school standards led to the design and implementation of a virtual tool to support academic achievement. Data came from a sample of 15 students' reading cycle reports, self-assessment of progress, questionnaires, and interviews. Results suggest that the developed VLO did promote the participants' appropriation of reading strategies proposed in the design of the course. The process with the VLO not only prompted higher reading comprehension, but also facilitated and enriched learning experiences.
\end{abstract}

Keywords: English for Specific Purposes (ESP), reading strategies, reading comprehension, Virtual Learning Object (VLO), virtual tool design.

\section{Resumen}

Este estudio tiene como objetivo describir la posible influencia de un objeto virtual de aprendizaje (OVA) en un grupo de estudiantes de comunicación social y periodismo en un curso de inglés para fines

Sandra Cecilia Hernández Urrego studied the Bachelor degree in Licenciatura en Lengua Castellana Inglés y Francés at Universidad de La Salle. She holds a Master's degree in Teaching foreign Languages at Universidad Pedagógica Nacional. Currently, She is a half- time English Teacher for different professional programs at Fundación Universitaria Uninpahu.

shernandezur@uninpahu.edu.co https://orcid.org/0000-0003-3550-2855

Received: April 10th, 2019. Accepted: June 14th, 2019

This article is licensed under a Creative Commons Attribution-Non-Commercial-No-Derivatives 4.0 International License. License Deed can be consulted at https://creativecommons.org/licenses/by-nc-nd/4.0/. 
específicos, quienes tenían dificultad para cumplir con los objetivos de lectura en inglés en una universidad privada de Bogotá (Colombia). Para efectos del estudio, se recolectaron datos de 15 estudiantes por medio de cuestionarios, entrevistas y de los reportes de los ciclos de lectura en la plataforma Moodle. Los resultados sugieren que el OVA promovió la implementación de las estrategias de lectura por parte de los participantes, mediadas por los ciclos y las etapas de lectura propuestas en el diseño de la herramienta. El proceso con el OVA no solo propició mejores habilidades de comprensión lectora, sino que también facilitó y enriqueció la experiencia con la lectura en inglés de los estudiantes.

Palabras clave: diseño de herramientas virtuales, estrategias de lectura, comprensión de lectura, inglés para fines específicos (ESP), objeto virtual de aprendizaje.

\section{Introduction}

Teaching faces different challenges in this era of Information and Communications Technology (ICT). One of them is the necessity to meet the demands of the information society and the adaptation of learners to work in an ICT environment. This passes by the tasks of providing prompt and friendly access to information. For this purpose, going beyond the language classroom walls can be achieved with the implementation of innovative ICT proposals that promote learners' reading competences and strategies. The sustained insertion of new technologies in the field of ELT has been documented by Lopera-Medina (2014). In addition, Clavijo Olarte, Hine, \& Quintero (2008) suggest that Virtual Learning Objects (VLOs) have proved to be dynamic, flexible, and cooperative and personalized vehicles to promote strategies for learning foreign languages in virtual environments, specifically reading strategies.

This paper reports the findings of an intervention carried out in a private institution of higher education in Bogota, Colombia. Despite the instruction and exposure to content in English for freshmen students of Social Communication and Journalism using ESP (Suárez-Montes \& Díaz-Subieta, 2015), students fail to comply with the English language requirements of the university, especially the ones related to their competences in reading in this target language. This evidence is reported taking into account a data triangulation plan (Sagor, 2000), which indicates the use of different perspectives to support the findings and collect the information (see Appendix). In this fertile scenario for innovation, a VLO was proposed for an ESP course as an alternative to promote and find evidence of the sustained use of reading strategies.

VLOs have become one of the most important modalities to further reading comprehension in universities. Nappa and Pandiella (2012) explain that VLOs and web resources provide many benefits for language learners. They develop skills for reading; they encourage independent learning and transfer English language content interactively. Students can communicate, exchange ideas, and work with other classmates through different activities (Nappa \& Pandiella, 2012). 
Additional research presents the VLO as a means to motivate students and build their self-confidence provided that it offers interaction, individualized instruction, and teacher support. There are other advantages to the VLO; for instance, Muñoz Arteaga et al. (2006) highlight important upsides of these web resources such as accessibility, flexibility, reusability, durability, educability, interactivity, and adaptability, which refer to the practices and procedures used in the actual teaching moment. These upsides were all considered in the current study.

Similarly, Barraza (2014) conducted a qualitative study which demonstrated that strategies enhanced reading through the utilization of a Virtual Lab. Aspects such as reading learning experience, effectiveness, interactive activities, and graphic organizers not only improved comprehension but made it enjoyable and practical.

In Colombia, the implementation of virtual tools for EFL has been a quintessential alternative to excel language learners' L2 competences. The use of ICT to read and write in college (Castillo, 2017), web-based courses fostering reading strategies namely, prediction, skimming, and scanning (Osorno-Gonzalez \& Lopera-Medina, 2012), as well as Crosscultural Virtual Forums displaying students' cultural stories by integrating reading activities and consolidating vocabulary (Clavijo Olarte, Hine, \& Quintero, 2008), exemplify the headway of virtual resources in the EFL local context. Considering the insights in these studies, the research question to answer in the current study is: What is a possible influence of a VLO in the promotion of reading strategies in ESP students of second semester of social communication and journalism? The following sections provide a description of the procedures to obtain an answer to this question.

\section{A Virtual Learning Object (VLO) to Teach Reading Strategies}

This segment discusses conceptual and theoretical considerations that underpin the study reported in this paper. A Virtual Learning Object (VLO) can be understood as a pedagogical mediator intentionally designed for a learning purpose. Arias-Soto, Buitrago-Escobar, and Pineda-Báez (2011) define it as "a vehicle for providing authentic material for the student to have contact with real language" (p. 35). In addition, these authors highlight other benefits

108 such as the development of reading skills in EFL and self-confidence in students. In the same vein, Wiley (2002) considers that VLOs allow the transit of learning models based on the construction of knowledge that permits the implementation of an intelligent teachinglearning environment. VLO acts as a useful device with its objectives and plans with which learners can mutually interact, learn, and propose their ideas.

As far as the advantages of incorporating interactive and technological strategies for ESP reading, Barraza (2014) suggests that they encourage independent learning by developing 
analysis and reflection, clarifying doubts, and transferring content, all of which can be used as control mechanisms and self-assessment. On the other hand, Wiley (2002) argues that those strategies help learners to expand the cognitive skills that they use to understand, select, organize, develop, and interpret the information they find in the VLO web resource. Overall, these aspects suggest that VLOs are more relevant in teaching and learning practices when the content and virtual functional quality are presented in a more attractive way for students to start working on reading activities.

\section{Reading Comprehension in EFL}

Neufeld (2005) understands reading as a process of making meaning in which there is a constant problem-solving exercise demanded by the interaction between the reader and the text. For Koda (2005), it entails "converting print into language and then to the message intended by the author" (p. 4). For Hellekjaer (2009), reading "comprises decoding the written text on the one hand and efficiently processing the information on the other hand" (p. 200).

Departing from the aforementioned conceptions of reading, Koda (2005) argues that comprehension happens when readers extract and process different information from the text and integrate it with their knowledge of the world. In this sense, reading constitutes a meaning-making process of constructing a supportable understanding of a text (Neufeld, 2005). Neufeld highlights two features in this comprehension process. First, seeking to comprehend a text is an active, intentional thinking process through which the reader constructs meaning. Second, during students' understanding of a text, this process varies because of their background knowledge and experiences. Thus, the reader attends to the information in the texts -encodes it- and constructs meaning through interaction and involvement with it. What the learner does to comprehend, encode, retrieve, and recall information is recognized as strategies, which are essential in reading development (Pang, 2008; Castillo, 2014).

For Snow Chair (2002), reading constitutes a heuristic comprehension process situated in a socio-cultural context and shaped by students' experiences, cultural practices, and background knowledge. Meaning construction entails transactions among the reader, the text, and the tasks; these change in the micro-developmental processes of pre-reading, duringreading, and post-reading, which show the transition of what the reader brings to the text and what they take from it.

Two fundamental reasons support this model. First of all, the variety of reading strategies that the model offers allows students to become active and purposeful readers able to monitor their own reading comprehension process. For instance, when students interact with the text, they recognize new vocabulary, organize and evaluate information, and 
establish connections with their own socio-cultural context; this shapes their background knowledge. A second reason is that reading strategies can be integrated to help learners understand specialized articles and texts in ESP. Each element of this micro-developmental process (the reader, the text, and the activity) interweaves and integrates one to another in permanent interaction.

Reading strategies should be practiced, reinforced, and refined continually. They are based on the complexity and extensiveness of the text that the individual is reading. These parameters become an alternative to tackle difficulties in the reading practice in ESP classrooms, as suggested in this paper. Drawing on Snow Chair's (2002) reading model, this current research study presents a proposal for teaching reading strategies in an ESP class. As Snow Chair (2002) suggests, by using different kinds of texts and tasks, the strategies applied were selected according to the students' ages, their conditions and needs.

Reading processes in English for Specific Purposes. According to Dudley-Evans and St. John (1998), reading in ESP is an approach centered on students' needs and interests to empower them to manage their understanding of technical and discipline-related texts. For Hutchinson and Waters (2005), ESP meets the learners' needs and reasons for learning, which determine the method and content to work in class. Likewise, Dhieb-Henia (2008) explains that ESP should provide learners with different types of activities to help them deal with the texts proposed. All of this facilitates two main processes: acquiring vocabulary and content, and establishing a dynamic interaction with further applications of knowledge. VLO would serve those purposes by integrating interactive resources such as videos, games, and animations.

In the current research study, VLOs constitute a pivotal variable since the virtual alternatives provide engaging learning experiences with contents of interest to audiences. The study then hopes to contribute to discussions on designing and implementing contextsensitive the VLO as a pedagogical mediation giving the potential that virtual tasks offer to enhance and monitor language development.

\section{Method}

The study employed representative features of a descriptive qualitative case study. It was based upon a problem previously identified (Merriam, 2009): a group of English students' failure to comply with reading competence objectives for an ESP course. The study is also situated in a specific setting, a private institution of higher education in Bogotá, with a group of fifteen second-semester students majoring in social communication and journalism who were taking an ESP course at the same institution, and whose ages ranged between 16 and 24 years. This characteristic relates to the case study paradigm as a bound system (Yin, 2014). For 
Hernández-Sampieri, Collado, \& Baptista-Lucio (2014), qualitative research focuses on "The understanding and deepening of the phenomena $[. .$.$] in a natural environment and in relation$ to the context" (p. 364). Accordingly, one of the main reasons for engaging in qualitative research was to address a specific situation that could bring about relevant transformative outcomes to the participants involved and to the educational setting in general.

The data informed both what happened when a VLO was introduced and the manner in which the 15 participants felt about what happened in the VLO. The emerging categories established the results of the study that revolved around the possible influence of the VLO in the promotion of reading strategies in the participants. Thus, data from the reports of the VLO reading cycle provided information to understand the participants' language development and their self-assessment at the end of the three cycles.

In addition, the responses to the questionnaire provided the insights that the participants gained from the activities and strategies of the VLO (Corbin \& Strauss, 2008). The semistructured interview (Merriam, 2009) captured the participants' perceptions and reasoning of what happened in the VLO, as well as tracked the most relevant strategies that informed their work with the VLO.

\section{Implementation of a Virtual Learning Object in ESP}

The VLO was designed using free software named EDILIM. The tool had 99 pages, which contained three reading cycles, each including a variety of texts about the cinema, movie directors, entertainment, design, and topics related to the participants' major. There were interactive activities with puzzles, crosswords, and word search for promoting reading strategies in ESP (Snow Chair, 2002). These contents and activities derived from the diagnostic assessment in which participants expressed their preferences and took into account their English language proficiency level. Similarly, most of the students who participated in this stage of the design of contents and activities considered it relevant for strengthening their reading strategies through online activities. In sum, both contents and purposes were articulated with Wiley's (2002) premises of quality for a virtual object, which should follow "a set of requirements that need[s] to be measured according to the needs of its users" (p. 117). The design of the VLO also considered the three elements proposed by Snow Chair (2002), namely the reader, the text, and the activity. The three elements intrinsically related to the participants' contexts. This followed the principle that elements are interwoven with three micro-developmental processes called, pre-reading, while reading, and post-reading.

VLO adjustments came after a piloting stage, which informed aspects of refinement in the VLO. As the researcher and developer of the implementation of this study, I acquired self-confidence and improved my abilities in designing and applying the data collection 
Table 1. Planning of the Reading Cycles

\begin{tabular}{|c|c|c|}
\hline Topics & Week & Activities/ Description \\
\hline Cycle 1 & $\begin{array}{l}\text { From October } \\
\text { 3rd Until } \\
\text { October } 21^{\text {st }}\end{array}$ & $\begin{array}{l}\text { 1. Topic: Famous Filmmaker Woody Allen } \\
\text { Objective. To identify details and use information to build } \\
\text { up meaning. } \\
\text { 2. 2. Topic: Colombiamoda } 2015 \text { as seen by a Spanish entrepreneur. } \\
\text { Objective. To identify details and use information to build up } \\
\text { meaning. } \\
\text { 3. 3. Topic: Colombia celebrates 'historic' Oscar Ceremony in spite } \\
\text { of not winning award. } \\
\text { Objective. To find main ideas in a specific context. }\end{array}$ \\
\hline Cycle 2 & $\begin{array}{l}\text { From October } \\
26^{\text {th }} \\
\text { Until } \\
\text { November } 8^{\text {th }}\end{array}$ & $\begin{array}{l}\text { 4. Topic: } 55 \text { Best Tips for a Successful Magazine Cover } \\
\text { Objective. To strengthen skimming and scanning reading strate- } \\
\text { gies. } \\
\text { 5. 2. Topic: Vintage Cover art forms. } \\
\text { Objective. To consolidate reading skimming and scanning stra- } \\
\text { tegies. } \\
\text { 6. 3. Topic: If Netflix Is Indeed Insourcing TV Production Then It } \\
\text { May Change TV Forever. } \\
\text { Objective. To improve the ability to understand and comprehend } \\
\text { newspaper articles. }\end{array}$ \\
\hline Cycle 3 & $\begin{array}{l}\text { From } \\
\text { November } \\
\text { 1oth Until } \\
\text { October 26th }\end{array}$ & $\begin{array}{l}\text { 7. Topic: The radio: Why listening to the radio gives us more } \\
\text { pleasure than watching TV or using a laptop } \\
\text { Objective. To predict possible facts based on information gotten } \\
\text { in newspaper articles. } \\
\text { 8. 2. Topic: Domestic abuse in The Archers- how the radio-show is } \\
\text { helping women spot signs. } \\
\text { Objective. To understand and comprehend newspaper articles by } \\
\text { the use of reading strategies. } \\
\text { 9. 3. Topic: Are intelligence sector reforms enough to protect Co- } \\
\text { lombia's journalists? } \\
\text { Objective. To take part in the solution of problems and concerns } \\
\text { from reading newspaper articles. }\end{array}$ \\
\hline
\end{tabular}


instruments. At the same time, the information that I gathered throughout the piloting served to sustain the pedagogical intervention (Merriam, 2009). Once the final version of the VLO was done, it was uploaded onto the Internet (http://itaemoodle.pedagogica.edu.co/). Then, it was implemented with the participants to facilitate the strengthening of reading strategies.

The lessons were organized in three cycles considering aspects such as objectives, reading-author(s), grammar, vocabulary, reading strategies, and assessment (Lopera-Medina, 2014; Craven, 2003). The students could recall and identify the reading strategies through self-assessment checklists presented in each reading cycle. This self-assessment in turn helped them monitor their reading progress. The three cycles were designed as follows:

Cycle 1 contained three simple short newspaper articles about cinema directors and entertainment; the students needed to identify details and build up meaning. Cycle 2 contained topics about magazines and Netflix productions. Finally, Cycle 3 included articles about the role of the radio and the importance of protecting journalists in Colombia. Hence, after participating in the previous two cycles, the students could take part in the solution to problems presented in the articles. Finally, final tests were designed to check students' reading comprehension of the topics and the use of the reading strategies suggested in the VLO.

The chart describes the organization of the VLO with a variety of tools associated with the students' field of action. I carefully designed and selected each of the readings, images, and activities to secure a good experience for the students. Information was presented with the main goals and instructions being to promote participation in an organized and sequential way. The tool displayed an array of options such as access to links, videos, dictionaries, and an online translator in order for students to make the most of their virtual learning process in ESP.

\section{Results}

Data collected through VLO reading cycle reports, questionnaires, and the semistructured interviews were analyzed through Sagor's (2000) 'coding data for analysis strategy.' This consisted of reading information, sorting it according to themes, and organizing it into codes and categories. For this particular study, I established a connection between the data and findings simultaneously. The units of analysis were identified in data by identifying the smallest but significant pieces of data that lead to finding patterns (Merriam, 2009). At the same time, I established a connection with the data and findings in order to identify hidden information. For the interviews especially, I used content analysis to interpret the participants' answers and to identify themes or patterns in them (Powers \& Knapp, 2006). The emerging categories (the VLO as a mediator for reading, reading strategies employed by 
Table 2 . Reading Stages and Sample Task

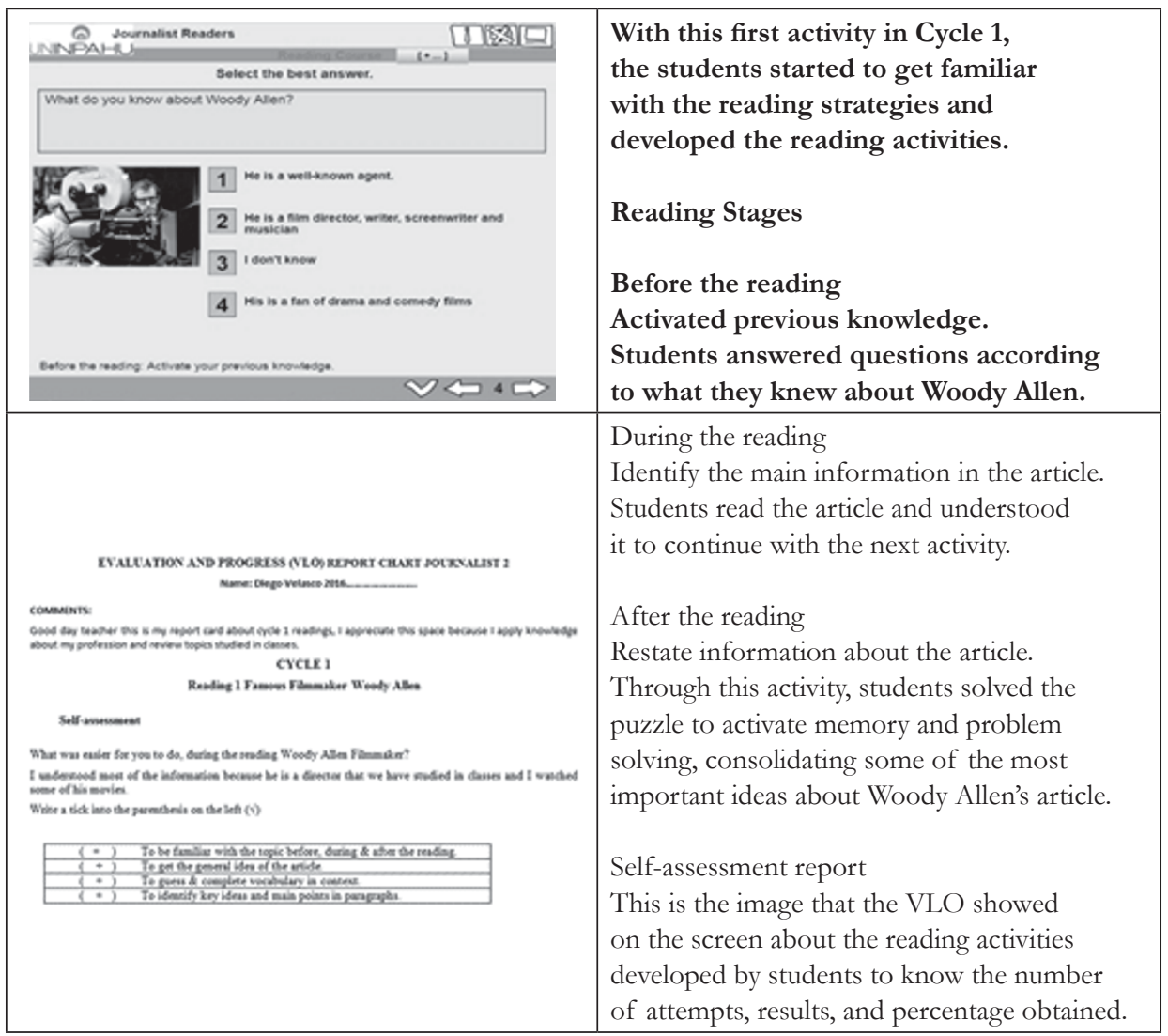

the students, and VLO reading strategies as a facilitator in reading comprehension) constituted the possible influence of the VLO in the promotion of reading strategies in the participants.

The VLO as mediator for reading strategies development in ESP. Nappa and Pandiela (2012) argue that the actual mediation of virtual tools increases interaction with texts while learners achieve an independence to read which would not otherwise be possible. Virtual tools also contribute to honing their sight word vocabulary, fluency, and management of new information, all of which are crucial for improvement in reading comprehension (Assia, 2012). The 15 participants interacted with multimedia activities in the VLO that allowed them to become familiar with ways to approach the texts. In the data obtained 
from participants, they identified a connection between the VLO and the activities that involved reading strategies. Thus, topics as "tools that enhance reading processes" (in the questionnaire) and "tools that enhance understanding" (questionnaire and interview) derived from the students' experience with the tool.

- S11: "I had never done reading activities online, which allowed me to learn new topics in English and fostered my confidence when reading."

- S13: "I had the opportunity to learn more about topics related to my profession by means of doing different readings and activities." [Question 1 - Questionnaire and Interview]

- Student 6: "The VLO was beneficial to know topics of great importance for my profession, helping me to learn new things." [Interview Question 13]

The data show that the VLO played the role to mediate for interaction between the participants and the texts evident through the way the students acknowledged the learning potential of the readings deployed in the virtual tool. Additionally, since the students were able to regulate their own reading process (Dhieb-Henia, 2008), more possibilities to gain confidence developing the reading practice in this alternative mode was evident too.

In the two last excerpts extracted from the interventions of students 13 and 6 , the connection between the reading contents proposed in the VLO and the professional context of the readers was perceptible. As stated in the literature review, the students then established connections with their own socio-cultural context by interacting with virtual texts, then shaping their background knowledge (Snow Chair, 2002).

Reading strategies employed by students in the VLO. The reading model chosen for this study worked as an umbrella frame for the implementation of reading strategies. Reading was conceived as a constructive, meaning-making process that involved the interconnection of four main elements: the reader, the text, the activity, and the context. It had to do with the reading strategies proposed by the Reading Study group (Snow Chair, 2002). The strategies were integrated through the following reading processes: before reading, during reading, and after reading. The data collected through the Moodle self-assessment report showed the following list of reading strategies that the students were aware of employing during the three cycles.

Table 3 shows the recurrence of using 17 identified strategies by the students. The column "yes" shows the number of students who used the strategy. The students exercised all of the reading strategies at some point of the process within each of the three cycles. I contend that getting familiarized with the VLO contents and dynamics, then using the 
Table 3. Self- Assessment Report for Reading Cycles 1, 2, 3

\begin{tabular}{|c|c|c|}
\hline I'm able to do it & Yes & No \\
\hline $\begin{array}{l}\text { 1. To associate the topic with the images, VLO'S multimedia activities and } \\
\text { tools provided. }\end{array}$ & $(15 s s)$ & - \\
\hline 2. To understand most of the vocabulary presented in the articles. & $(14 s s)$ & - \\
\hline 3. To be familiar with the topic before, during \& after the reading. & $(15 s s)$ & - \\
\hline 4. To understand the general and specific ideas in the articles. & $(15 s s)$ & - \\
\hline 5. To identify key ideas in paragraphs. & $(14 \mathrm{ss})$ & $(1 \mathrm{~s})$ \\
\hline 6. To predict and infer information from the text. & $(15 s s)$ & - \\
\hline $\begin{array}{l}\text { 7. To identify the reading strategies in the articles: activating previous } \\
\text { knowledge, skimming, scanning, identifying main ideas, relating vocabu- } \\
\text { lary, summarizing and asking question about the topic. }\end{array}$ & $(15 s s)$ & - \\
\hline $\begin{array}{l}\text { 8. To improve through the reading process key information to build up } \\
\text { meaning. }\end{array}$ & $(14 s s)$ & $(1 \mathrm{~s})$ \\
\hline 9. To read more often for improving my understanding. & $(14 s s)$ & $(1 \mathrm{~s})$ \\
\hline 10. To use the vocabulary learnt in other readings. & $(15 s s)$ & - \\
\hline 11. To guess words' meanings from reading context. & $(14 \mathrm{ss})$ & $(1 \mathrm{~s})$ \\
\hline 12. To associate and activate my knowledge with the readings. & $(15 \mathrm{ss})$ & - \\
\hline 13. To understand a greater percentage of the readings. & $(13 \mathrm{ss})$ & $(2 \mathrm{ss})$ \\
\hline 14. To explain the articles' importance associated with my profession. & $(15 s s)$ & - \\
\hline 15. To relate the readings of articles to my own experiences. & $(15 \mathrm{ss})$ & - \\
\hline 16. To reflect on what I learned from the article. & $(14 s s)$ & $(1 \mathrm{~s})$ \\
\hline $\begin{array}{l}\text { 17. To take part in the solution and concerns from reading newspapers } \\
\text { articles. }\end{array}$ & $(14 \mathrm{ss})$ & $(1 \mathrm{~s})$ \\
\hline 18. To enjoy and being an active reader. & $(15 \mathrm{ss})$ & - \\
\hline
\end{tabular}

integrated tools (videos, links, and presentations to orient the student) were of paramount importance for the achievement of this result.

In the interview conducted with the students at the end of the process, they could notice that the activities proposed had a purpose in each cycle. That purpose was articulated with the reading strategies as general guidelines, oriented to have the students find out how to read and answer reading comprehension questions in a specific article. 
- S6: "The Reading strategies promoted by the VLO were effective because they guided us a lot. They are like guidelines on how to read in every moment, before, during and after reading and answer the questions in the article."

Interview- Question 5: What are the strategies you found more useful?

- S7: "Activation of previous knowledge, skimming, scanning, predicting, main idea identification, vocabulary association, concluding and making questions about the article." [Questionnaire and Interview]

The data collected in the final questionnaire showed that the students learnt how to read and understand a text in English by using reading strategies, as these allowed them to understand the articles better. VLOs are generally conceived to have added values in the teaching and learning process in ESP, since the participants benefited from the possibilities these tools offered. Some of these were practicing with readings and related activities to discover reading strategies that fostered reading comprehension of specialized texts in English.

VLO reading strategies as facilitator in reading comprehension. Reading comprehension is the process of capturing and constructing meaning from a text; in this case, a written text included in the VLO. It is the result of the interaction that occurs when the text itself, the reader, and the context interweave (Neufeld, 2005). Speaking of the text itself, I highlight the fact that the students were able to tap on the design and approach used to distribute readings in the VLO, namely, the organization by cycles and the microdevelopmental processes (pre-reading, during-reading, and post-reading).

The students learned how to read and understand a text in English by using the reading strategies abovementioned, as these allowed them to understand the articles better. The following excerpts demonstrate how the VLO equipped them with tools to understand the texts presented.

- S8: "The strategies were necessary to comprehend texts more accurately, starting from the 'before Reading' part. That allows approaching better to the text and they are good to improve vocabulary and be able to draw conclusions about the Reading."

- S9: "The Reading strategies allowed me to make meaning of the topics, to see what the author wants to convey."

[Interview Question 13 - Questionnaire and Interview]

The incorporation of the VLO highlighted the fact that both the teachers and students worked in a friendly environment that benefited their practices, and enhanced the pedagogical expertise and engagement with learning (Beatty, 2012). With the VLO, the participants expanded knowledge and practiced English more in interactive activities such as puzzles, 
games, crosswords, and word search, among others. The participants expressed that, with the strategies, they learned to navigate through activities and were able to map the texts.

With respect to the VLO cycles, the participants were able to identify details and build up meaning from texts in the first cycle. In cycle two, the participants practiced to increase their capability to understand newspaper articles, and, in cycle three, the participants proposed solutions to the issues presented in the newspaper articles. The data in Figures 1 and 2 below, extracted from the VLO reading cycle reports with Moodle, contrasts the total of correct answers to reading comprehension requirements.

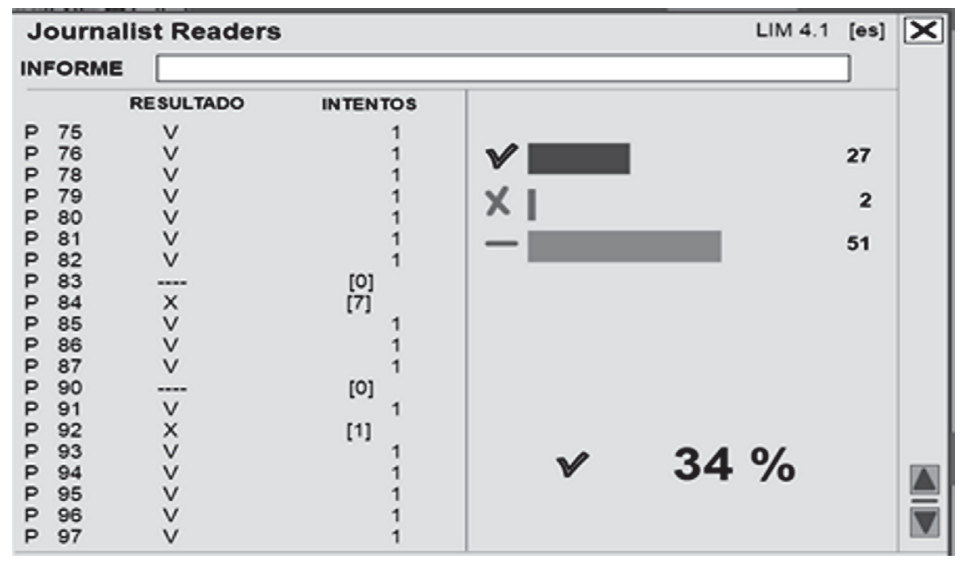

Figure 1. Example of Moodle Reading Report - Evaluation and Progress.

Figure 1 shows the students' progress in their comprehension abilities. Only one participant resorted to seven tries, but all of them could do crosswords, sentence-matching, and word search to check understanding on their own. This flexibility was not available in direct classroom instruction. The participants took an initial test before the pedagogical intervention and a final one after it. Figure 2 contrasts those results to shed light on the effectiveness of promoting reading strategies to comprehend written texts in ESP mediated by a VLO.

The graphic of the initial and final tests provides a picture of the significant difference between the results that the students obtained before and after the implementation of the VLO. This shows that the students could have taken advantage of the use of reading strategies when dealing with newspaper articles in ESP. Consequently, the participants showed an overall increase in the outcome in reading comprehension. Regarding the objectives of the test, these results suggest that the students, over time, become more equipped with the linguistic competences they need in their professional life as social communication or journalism students. 


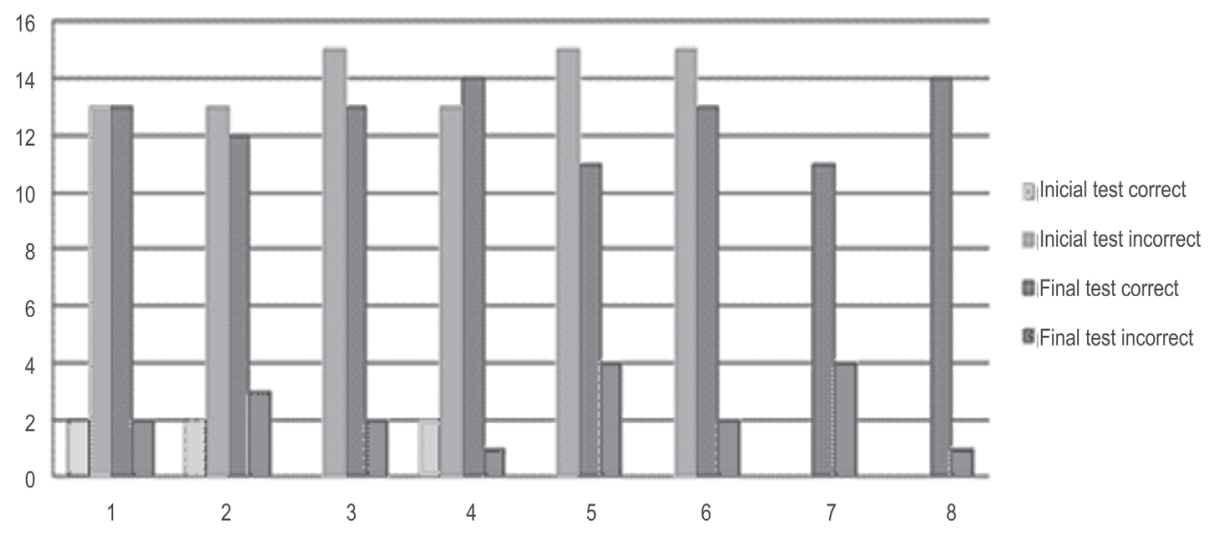

Figure 2. Initial Test vs. Final Test results.

\section{Conclusions}

According to the results presented in this paper, VLOs serve to promote reading strategies for ESP courses. That promotion depends greatly on the way VLO resources are deployed, which in this study meant setting manageable learning objectives, grading and selecting texts and topics that are sensitive to the learners' needs, and including an informed selection of engaging games and activities. In this manner, VLOs mediate and ease interaction between students, teachers, and texts. This paper postulates that the development of reading strategies constitutes the core of a successful pedagogical intervention and that the support of VLO contributes to it. The results presented above attest to the participants' efforts of meaning-making.

Furthermore, these results showed that the students became aware of the importance of the reading strategies promoted by the VLO in order to understand better the process involved in interpreting newspapers and academic texts. This happened with the use of strategies such as activating previous knowledge, skimming, scanning, inference, or drawing conclusions. The increase in comprehension can be attributed to the work done on the VLO. The final reading test showed the progress in understanding the texts.

The participants also strengthened their knowledge and the strategies necessary to tackle academic and scientific texts. They were able to recall and identify reading strategies in the self-assessment checklists of each report of the VLO reading cycle. The evidence gathered from the reports in the Moodle platform of the course consisted of the participants' selfassessment and the work done in the three cycles monitored by the teacher. The participants coped with the difficulties found in terms of the appropriation of the concepts and resources presented in writings. Consequently, this enhanced their linguistic repertoire for coping with 
articles and reports on social communication and journalism. This assertion derives from the contrast of the students' responses in the interviews, questionnaires, and reports at the beginning and at the end of the implementation.

Upon analyzing the data of the VLO's implementation there was evidence that the participants followed the reading sequence proposed by Snow Chair (2002) for before, during, and after the reading; this was manifested in interviews. The proposed reading sequence acted as an interconnecting method and a promoter of specific orientations that determined somehow the reading process that participants underwent when using the VLO.

From the intervention with the VLO in this population, it can be inferred that the use of reading strategies promoted by the VLO went a long way in establishing connections between the students' own socio-cultural context and texts, thus enhancing their background knowledge. In this respect, it can safely be claimed that VLO provided learners with tools to facilitate and enrich their overall reading and learning experience.

\section{References}

Arias-Soto, L. D., Buitrago-Escobar, Z. R., \& Pineda-Baéz, C. (2011). ICT in the professional developments of EFL teachers: Perceptions and challenges. Folios, 33, 25-42.

Assia, B. (2012). CT and reading: In the technology- enhanced extensive reading classroom. Revue Académiques des Sciences Sociales et Humaines, 8(3), 3-16.

Barraza, J. V. (2014). Using interactive graphical and technological strategies for EFL reading comprehension: A case study involving engineering students. Colombian Applied Linguistics Journal, 16(1), 29-39.

Beatty, K. (2012). Teaching and researching computer language learning. Cambridge: Cambridge University Press.

Castillo, R. (2014). Teaching and learning another language strategically. Bogotá: Universidad Distrital Francisco José de Caldas.

Castillo, R. (2017). Changing the course: Interpreting and structuring scientific texts aided by ICT. Latin American Journal of Content and Language Integrated Learning, 10(2), 245-270.

Clavijo Olarte, A., Hine, N. A., \& Quintero, L. M. (2008). The virtual forum as an alternative way to enhance foreign language learning. Profile: Issues in Teachers' Professional Development, 9(1), 219-236.

Corbin, J., \& Strauss, A. (2008). Basics of qualitative research: Techniques and procedures for developing grounded theory (3rd ed.). Thousand Oaks, CA, US: Sage Publications, Inc.

Craven, M. (2003). Reading keys. Thailand: Macmillan Publishers Limited.

Dhieb-Henia, N. (2008). Designing an e-learning ESP course. Possibilities and challenges. CALLEJ Online, 9(2), 1-7. 
Dudley-Evans, T., \& St. John, M. J. (1998). Developments in English for specific purposes: A multi-disciplinary approach. Cambridge: Cambridge University Press.

Hellekjaer, G. O. (2009). Academic English reading proficiency at the university level: A Norwegian case study. Reading in a Foreign Language, 21(2), 198-222.

Hernández-Sampieri, R., Collado, C. F., \& Baptista-Lucio, M. (2014). Metodología de la investigación (Vol. 5). México: Mc Graw-Hill.

Hutchinson, T., \& Waters, A. (2005). English for specific purposes. Cambridge: Cambridge University Press.

Koda, K. (2005). Insights into second language reading - A cross-linguistic approach. Cambridge: Cambridge University Press.

Lopera-Medina, S. (2014). Motivation conditions in a foreign language reading comprehension course offering both a web-based modality. Profile: Issues in Teachers' Professional Development, 16(1), 89-104.

Merriam, S. B. (2009). Qualitative research: A guide to design and implementation. San Francisco, US: Jossey-Bass Publications.

Muñoz Arteaga, J., Álvarez Rodríguez, F. J., Osorio Urrutia, B., \& Cardona Salas, J. P. (2006). Objetos de aprendizaje integrados a un sistema de gestión de aprendizaje. Apertura, 6(3), 109-117.

Nappa, N. R., \& Pandiella, S. B. (2012). Estudio y aplicación de objetos de aprendizaje a través del uso de recursos educativos abiertos. Revista Electrónica de Tecnología Educativa, 1(39), 1-17.

Neufeld, P. (2005). Comprehension instruction in content area classes. International Reading Association, 59(4), 302-312.

Osorno Gonzalez, J. A., \& Lopera Medina, S. A. (2012). Interaction in an EFL reading comprehension distance web-based course. Ikala, Revista de Lenguaje y Cultura, 17(1), 45-59.

Pang, J. (2008). Research on good and poor reader characteristics: Implications for L2 reading research in China. Reading in a Foreign Language, 20(1), 1-18.

Powers, B. A., \& Knapp, T. R. (2006). Dictionary of nursing theory and research (3 ${ }^{\text {rd }}$ Ed.). NY, USA: Springer Publishing Company.

Sagor, R. (2000). Guiding school improvement with action research. Alexandria, Virginia USA: ASCD.

Snow Chair, C. (2002). Reading for understanding: Toward a research and development program in reading comprehension. Santa Monica, California: Rand.

Suárez-Montes, N., \& Díaz-Subieta, L. B. (2015). Estrés académico, deserción y estrategias de retención de estudiantes en la educación superior. Salud Pública, 17(2), 300-313.

Wiley, D. A. (2002). The instructional use of learning objects. Bloomington, Indiana: Agency for Instructional Technology and Association for Educational Communications \& Technology.

Yin, R. K. (2014). Case study research- Design and methods (Vol. 5). Newbury Park, CA: Sage. 
Sandra Cecilia Hernández Urrego

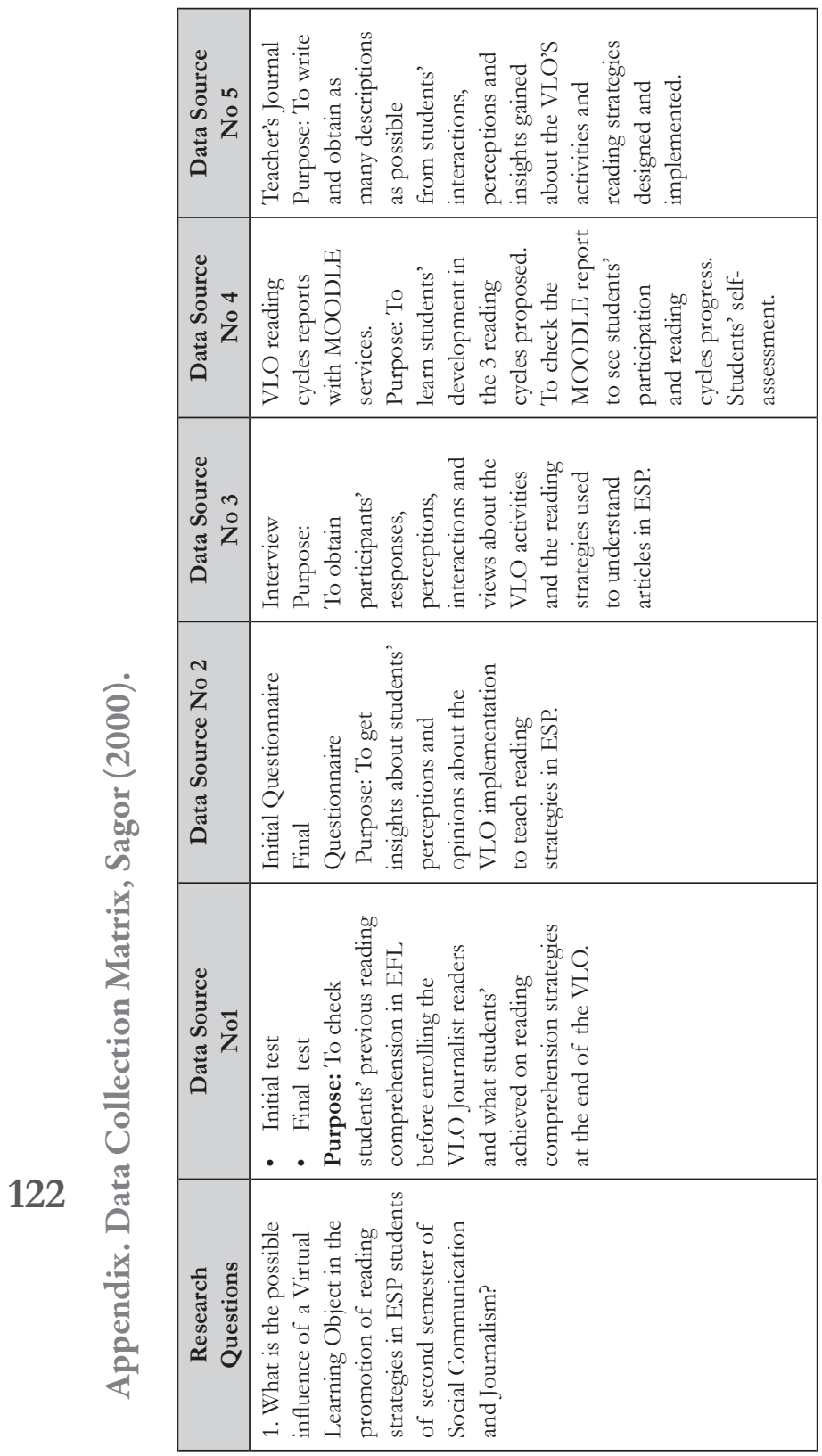

HOW 